\title{
Antistatic polyethylene free-standing films modified with expanded graphite - technological aspects
}

\author{
Paweł Imiołek ${ }^{1)}$, Krzysztof Kasprowicz ${ }^{2)}$, Jadwiga Laska ${ }^{1), *)}$ \\ DOI: dx.doi.org/10.14314/polimery.2020.4.3
}

\begin{abstract}
The main goal of this research was to develop antistatic polyethylene films with a surface resistance of $\leq 10^{9} \Omega$. The research involved testing low density polyethylene/linear low density polyethylene (PE-LD/PELLD) filled with various amounts of expanded graphite EG 096. The samples were made by hot pressing and injection molding. Mechanical and electrical properties were tested. The research results show that samples with a content of $30 \%$ by weight of expanded graphite are characterized by good mechanical properties, e.g. Young's modulus of the filled PE was higher by $195 \%$ compared to pure polyethylene.
\end{abstract}

Keywords: polyethylene, expanded graphite, antistatic films.

\section{Antystatyczne folie polietylenowe modyfikowane grafitem ekspandowanym - aspekty technologiczne}

Streszczenie: Głównym celem prezentowanych badań było opracowanie antystatycznych folii polietylenowych o oporności powierzchniowej $\leq 10^{9} \Omega$. W pracy zbadano polietylen małej gęstości (PE-LD/PE-LLD) napełniony różną ilością grafitu ekspandowanego EG 096. Próbki wykonano metodą prasowania na gorąco i formowania wtryskowego. Zbadano ich właściwości mechaniczne oraz elektryczne. Na podstawie wyników badań stwierdzono, że próbki o zawartości 30\% mas. grafitu ekspandowanego charakteryzują się korzystnymi właściwościami mechanicznymi, np. moduł Younga napełnionego PE był o 195\% większy niż polietylenu bez udziału napełniacza.

Słowa kluczowe: polietylen, grafit ekspandowany, folie antystatyczne.

The goal of the presented research was to elaborate antistatic additives for polyethylene for the production of thin films. The presented article aims at popularizing the results of the research which was conducted in the years 2015-2018 by the University of Science and Technology in Kraków, Poland, and Pakpoland Sp. z o.o. as a part of a research and development project No. POIR. 01.01.01-00-1005/15-00.

This article presents the results of research on the modification of polyethylene with expanded graphite.

Among all polymers produced on an industrial scale, polyolefins are the most important ones, and this includes polyethylene, which due to its mechanical and processing properties has found a wide use in the production of films, packaging, containers and other everyday use items. Polyethylene is very light and shows a high resistance to most solvents, acids and bases. It is also an excel-

\footnotetext{
1) AGH University of Science and Technology, Faculty of Materials Science and Ceramics, al. Mickiewicza 30, 30-059 Kraków, Poland.

2) Pakpoland Sp. z o.o., Szybowcowa 1, 87-853 Kruszyn, Poland.

*) Author for correspondence: jlaska@agh.edu.pl
}

lent insulating material that does not erode. The abovementioned properties allow for a wide use of polyethylene for the production of insulation of cables, gas pipelines, water supply, sewerage, packaging, including transport and storage of acids and bases, among others. According to the Association of Plastics Manufacturers report, the production for plastics in Europe reached 64.4 million tonnes in 2017 (60 $\mathrm{mln} \mathrm{t}$ in 2016) [1]. The demand for low density polyethylene (PE-LD and PE-LLD) was almost 9 million tonnes, which is $17.5 \%$ of all used plastics [2]. The largest sales market for polyethylene is the region of Asia and Pacific, which in 2013 consumed approx. 11.3 million tonnes of PE-LLD itself and over 7 million tonnes of PE-LD. It is estimated that in the coming years the value of the PE-LLD market will increase by $3.9 \%$ per year, while PE-LD will increase by $1.5 \%$ annually [3].

The surface resistance of commonly used polyethylenes such as PE-LD, PE-LLD and PE-HD is $>10^{12} \Omega$, and the cross resistance is $>10^{16} \Omega$. High surface resistance of polyethylene is a significant obstacle to some applications of these materials. Due to the exceptional ease of accumulation of electric charges on the surface of the material, there is a risk of an electric spark with a voltage of several dozen thousand volts being formed, capable of causing an explo- 
sion or fire, depending on the environment in which this occurs. At the same time, the development of technology demands more and more from scientists in terms of the optimization of production processes. Global competition enforces lowering production costs through faster and more automated production processes. Those production processes consist in fast rewinding, coating, rotating and turning of pulleys, V-belts, transmission belts, rolling, extruding or calendering. During production, as well as transport and storage, an electric charge may accumulate on the surface and, as a consequence, fire and explosion hazards arise. Wherever there are explosion or fire risks related to static electricity, it is necessary to use safe antistatic materials whose surface resistivity will be at $\leq 10^{10} \Omega$.

Antistatization is intended to change the resistive parameters of materials, often changing the plastic category from an insulator to a diffusing material [4]. Such a result can be obtained by applying an antistatic substance to the surface of the material or by modifying the polymer matrix which will possess immanent antistatic features [5]. Although methods of material antistatization have been known for a long time, it is necessary to adapt them to a specific material, and also take into account many aspects of use such as product transparency and colour, approval for contact with food, mechanical strength, weldability, etc. Reasonably low surface resistivity of a material is important, in particular, when using polyolefin products in fire hazard zones, as well as in electronics. The electrical conductivity of packaging, for example, can have a positive or negative effect on product safety. The issue of durability of material antistatization is still open.

Expanded graphite is a light material produced in a thermal expansion of intercalated graphite. Intercalation of graphite occurs in the process of treatment of crystalline graphite with strong acids like sulfuric or nitric acid in elevated temperatures. Heating intercalated graphite results in an increase in volume of up to 100 times. Multilayer structures characteristic to natural flake graphite, worm structures, and nanoparticles of high shape factor are created. Expanded graphite shows melting point over $3850^{\circ} \mathrm{C}$, and the boiling point $\mathrm{ca} .4250^{\circ} \mathrm{C}$. The layered structures induce reasonably high thermal and electric conductivity, what predestine it as an highly effective antistatic additive to polymers.

Modification of polyethylene with expanded graphite was a subject of many studies [6-9]. The research shows increase of electric conductivity of polymer composites upon loading with expanded graphite. In our research we focused on thin free-standing films of PE-LD/PE-LLD with addition of EG obtained in extrusion-blowing process.

\section{EXPERIMENTAL PART}

\section{Materials}

PE-LD (type FGNX) - low density polyethylene was purchased from Basell Orlen Polyolefines, Poland.
PE-LLD (Lotrène Q1018N) - linear low density polyethylene was purchased from Qatofin Company Limited, Qatar.

EG 096 - expanded graphite was purchased from Sinograf SA, Poland.

\section{Sample preparation}

The premix containing $30 \mathrm{wt} \%$ of expanded graphite, $30 \mathrm{wt} \%$ PE-LLD and $40 \mathrm{wt} \%$ PE-LD was prepared at Pakpoland SA by mixing PE granules and graphite powder in a fluidized bed mixer. The premix was used to obtain a series of mixtures with different EG contents [wt \%]: 3, 5, 6, 7, 10, 15, 20 and 30. Suitable moldings for further tests were obtained by injection molding and hot pressing.

Samples in the form of paddles compliant with the PN-81/C-89034 standard were made on a Multiplas V4-S-15N vertical injection molding machine (Taiwan) at an injection temperature of $200 \pm 5^{\circ} \mathrm{C}$. Samples for testing electrical properties (surface resistivity and volume resistivity) and flammability in the form of plates sized $[\mathrm{mm}] 100 \times 100 \times 2$ were prepared by hot pressing at $150^{\circ} \mathrm{C}$ and $1 \mathrm{MPa}$ pressure.

\section{Methods of testing}

The strength tests were made on a universal testing machine - Shimadzu Autograph AGS-X (Japan). The sample tensile test was made at a speed of $10 \mathrm{~mm} / \mathrm{min}$ (according to EN ISO 527-1). Stretching curves were recorded at $50 \mathrm{~ms}$ sampling. The bending tests were made on samples with a length of $25 \mathrm{~mm}$ using the three-point method (loading speed of $5 \mathrm{~mm} / \mathrm{s}$ ).

The measurement of surface resistivity and volume resistivity was made using a pocket surface resistance meter SRM 200 (Wolfgang Warmbler) - linear electrodes, and an apparatus consisting of a Keysight B2987A (USA) picometer/electrometer, 16008B measuring cell consisting of a protective, measuring and voltage electrode, and a computer with Keysight software. Samples in the form of plates sized [mm] $10 \times 10 \times 2$ prior to conducting the tests were removed from the surface charge by being placed between two metal plates. The measurement was made for 120 seconds, a voltage of $100 \mathrm{~V}$ was applied, the range of the measured electrical current was from $2 \mathrm{pA}$ up to $200 \mu \mathrm{A}$. A protective electrode was used in the surface resistance measurement. The measurement was recorded in the form of graphs of change in intensity as a function of time.

\section{RESULTS AND DISCUSSION}

Figure 1 shows the dependence of elongation at break of samples of polyethylene modified with the addition of expanded graphite. The addition of even $15 \mathrm{wt} \%$ of expanded graphite in the polyethylene matrix practically 


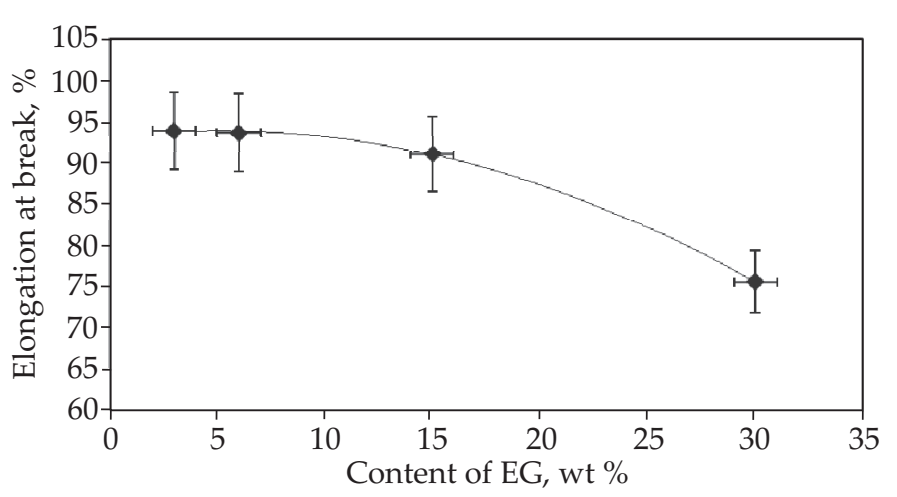

Fig. 1. The dependence of elongation at break of PE/EG samples on the expanded graphite content

does not cause deterioration of the elongation at break, which is $\sim 90 \%$ of the initial length, while the content of $30 \mathrm{wt} \%$ of expanded graphite results in the break of samples already at $50-60 \%$ of elongation. Samples with an EG content of $30 \mathrm{wt} \%$ were also characterized by the highest dispersion of the measurement values, which means low reproducibility of the results (Fig. 2).

Similarly, the stress required to break the sample does not depend on the presence of EG up to its content of

a)

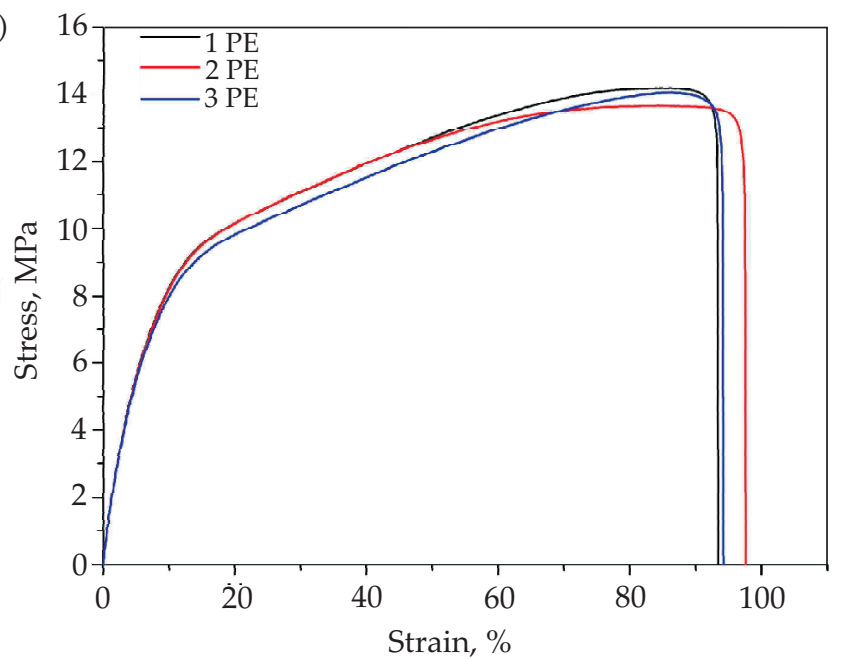

b)

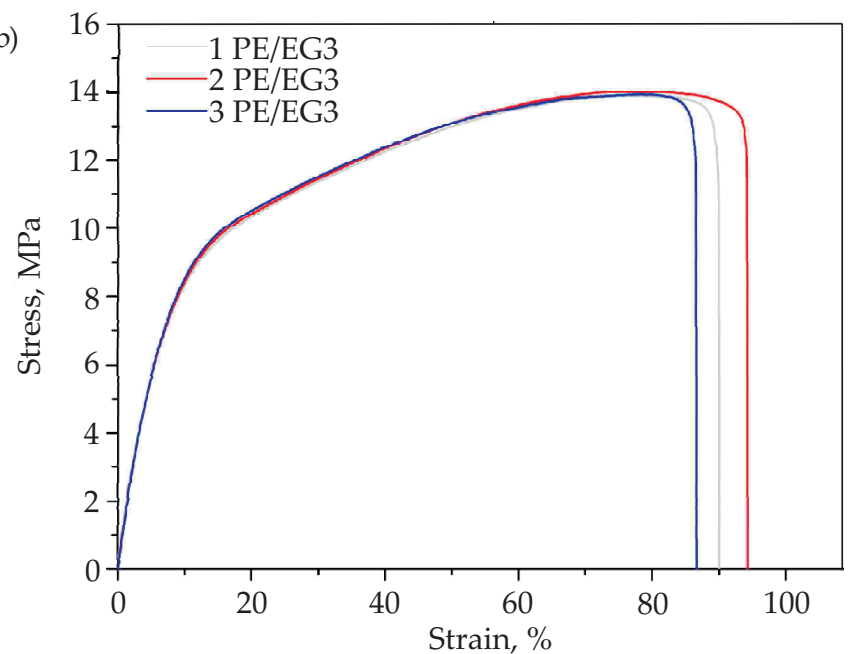

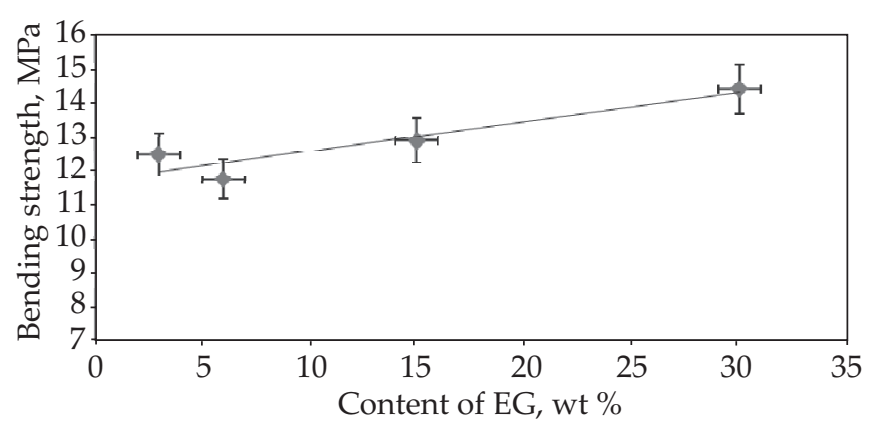

Fig. 3. The dependence of bending strength of PE/EG samples on the expanded graphite content

$15 \mathrm{wt} \%$, and its value is approx. $14 \mathrm{MPa}$, while the addition of $30 \mathrm{wt} \%$ causes a slight reduction of the stress value to 12-13 MPa. Simultaneously, the stretching curves show that with the graphite content of $\geq 30 \mathrm{wt} \%$, the nature of the sample's changes from elastic to plastic. This is related to the layered structure of graphite and the effect of sliding of these layers. In turn, the elastic nature of samples with lower graphite contents (the stretching curves of these samples are analogous to that of polyethylene) points to the exfoliation of graphite with polyethylene. Increasing the graphite content results in a proportional increase in Young's modulus and the shift of the yield point to higher stress values. Young's modulus for samples containing 3, 7, 15 and $30 \mathrm{wt} \% \mathrm{EG}$ is 175, 190, 220 and $358 \mathrm{MPa}$, respectively, and tensile strength is 14.2 , 13.7, 13.65 and $13.25 \mathrm{MPa}$, respectively.

The increase in strength along with the graphite content was also observed in bending tests (Fig. 3). An increase in bending strength along with an increase in graphite content was observed. The highest value of nearly $14.5 \mathrm{MPa}$ was observed for the content of EG 30\% by weight, the lowest for $7 \%$ by weight. For technical reasons, the bending strength was tested up to $25 \%$ deformation of the sample shape. With this deformation, no sample was destroyed.

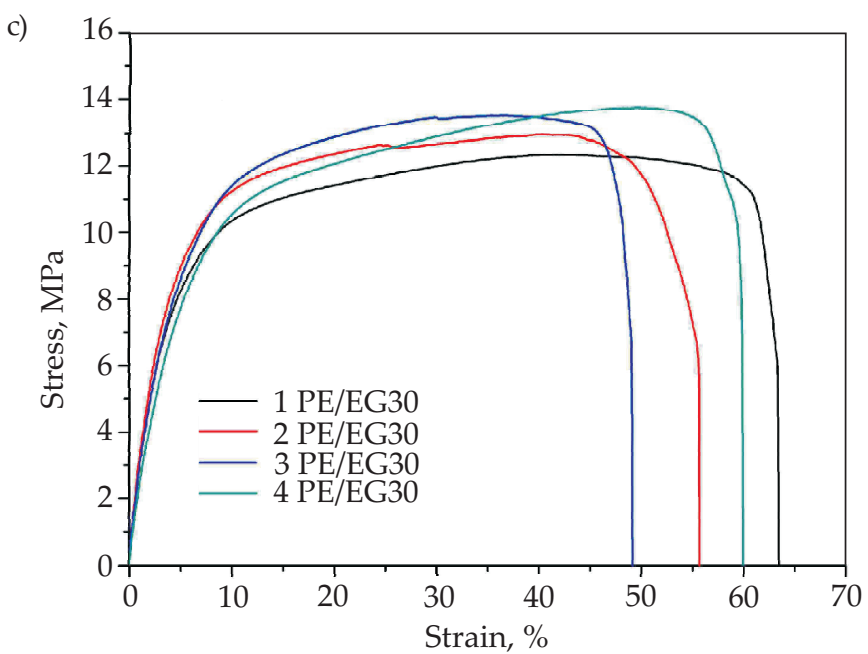

Fig. 2. Stretching curves of PE/EG samples: a) polyethylene without additives, b) addition of $3 \mathrm{wt} \%$ of EG, c) addition of $30 \mathrm{wt} \%$ of EG 


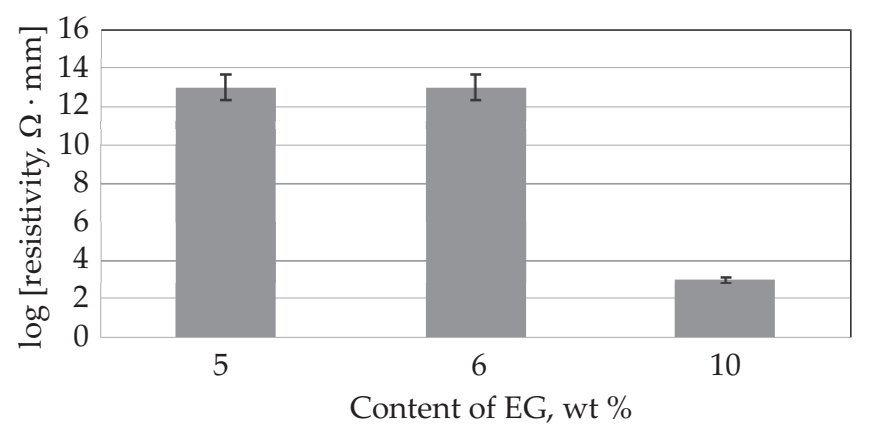

Fig. 4. Surface resistance of PE/EG samples depending on expanded graphite content

The current characteristics of the tested samples were recorded by measuring the change in intensity over time, which was then transformed into surface resistivity $R_{p}$ as a function of time $R_{p}=\mathrm{f}(t)$. Sample resistance depending on the EG content is shown in Fig. 4. The addition of $10 \mathrm{wt} \%$ of EG results in a rapid drop in surface resistance of up to $10^{3} \Omega$.

The surface resistivity is shown in the diagrams in Fig. 5 . The presented characteristics are characterized by
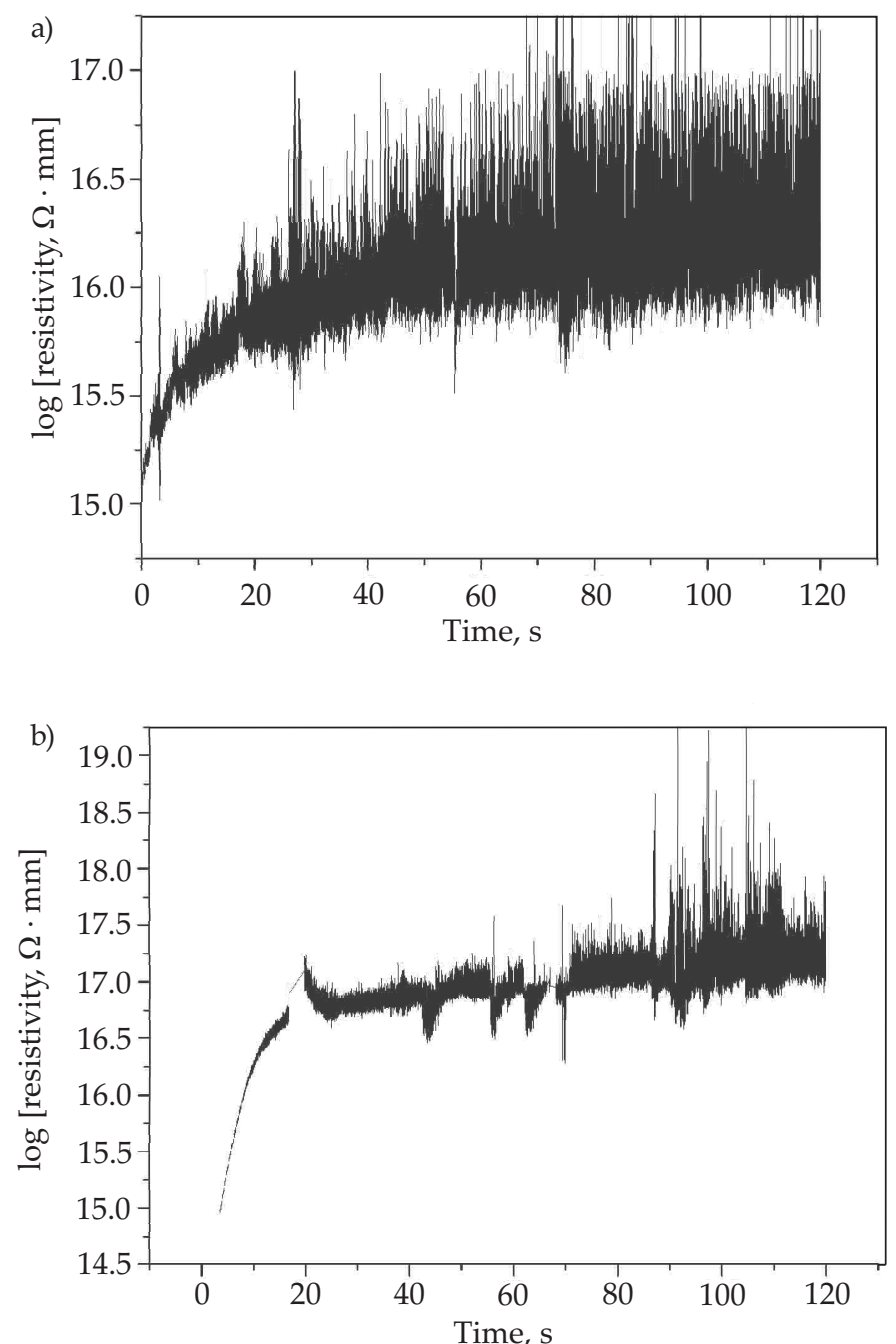

high instability, large changes in resistance are visible in time, which is probably related to the too big distance between graphite flakes and the break of the electron transport path. Increasing the graphite content decreases the surface resistivity value, a $10 \mathrm{wt} \%$ addition of graphite results in a decrease of surface resistivity to $10^{5}(\Omega \cdot \mathrm{mm})$. The large specific surface area of graphite results in the fact that exceeding $10 \%$ by weight in the composite allows achieving a large volume of this additive in the composite and a marked decrease in resistivity of the samples. The homogenization of the composite is also important. The presented characteristics show that the surface resistivity, regardless of the graphite content, does not drop below $10^{14}(\Omega \cdot \mathrm{mm})\left(10^{11}-10^{12} \Omega\right)$. The highest current stability was characterized by a composite containing $30 \mathrm{wt} \%$ of graphite (Fig. 5).

Increasing the graphite content reduces the surface resistivity value, which means that the composite structure can be manipulated, resulting in a decrease in surface resistivity even to $10^{8} \Omega$. However, the measurements made on the test plates showed great instability of the results, most likely due to the fact that the additive particles do not form a homogeneous and related structure, which translates into a current flow. An additional factor affecting the research results is the method of manufacturing the product. A special process of mixing components allows obtaining the correct level of resistivity. It also allows for a $50 \%$ lower use of components. Different electrostatic properties will be visible in a product made by pressing, by injection method, by extrusion, and blow molding. An optimal filling of the polymer matrix with the active substance can change the results regarding the current flow, due to the possibility of breaking the molecular chains of the active ingredient during the blowing and longitudinal orientation of the film in the extrusion process. A radical increase in the filling reduces the surface resistivity value, but in the case of extrusion with blow molding of film, problems with the blow itself and the effects of the orientation of the film arise.

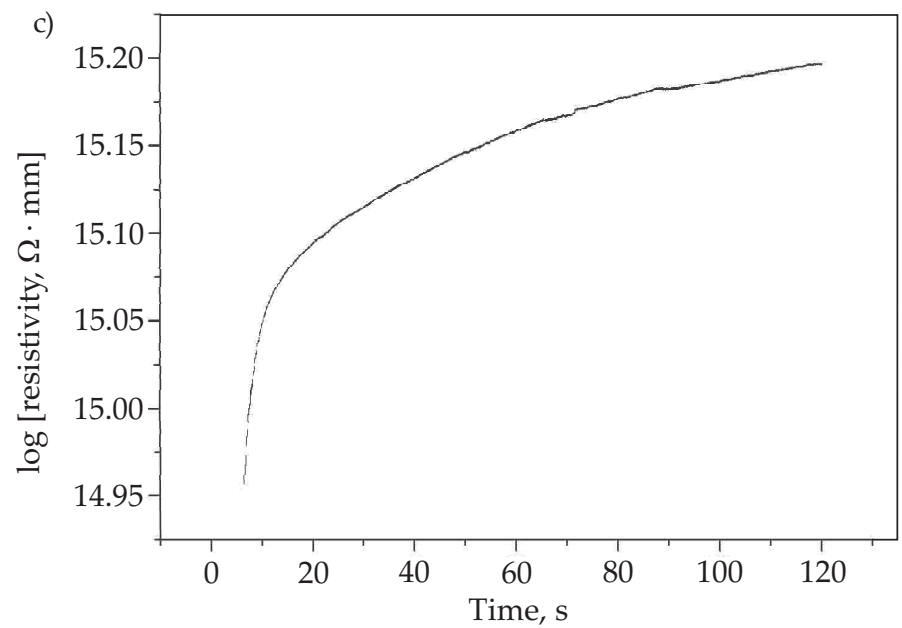

Fig. 5. Surface resistivity of PE/EG samples as a function of time: a) $3 \mathrm{wt} \%$ of EG, b) $7 \mathrm{wt} \%$ of EG, c) $30 \mathrm{wt} \%$ of EG 


\section{TECHNOLOGICAL ASPECTS OF THE CONDUCTED RESEARCH}

The conducted research on the films with the use of nanotubes, graphene and soot showed that good results can be obtained in this respect, but with relatively high filling which, in turn, requires taking into account the costs of such a result, considering the high prices of nanopowders, graphene or nanotubes. Economic reasons have led to the discontinuation of further research in this regard.

The results of surface or cross-resistance measurements usually differ from the actual values. These differences are a measurement error. Results of numerous (several hundred attempts) measurements of surface resistance or cross resistance of polyethylene film made at Pakpoland Sp. z o.o. have never exactly repeated themselves, which means that it is an extremely volatile matter, the result of which can be obtained through careful research that would only allow getting closer to real values. The uncertainty of the measurement results and reasons for this phenomenon is described in more detail by M. Lisowski [10].

The results of surface resistivity of materials (e.g. polyethylene) are also influenced by the processing method, in particular, when dealing with extruded material blowing. Film extrusion with the blowing method causes that other surface resistance results are obtained by testing the longitudinal resistance of foil, and other by testing transverse resistance. The transverse orientation of film results in a greater degree of breaking of the paths of antistatic components contained in the polymer matrix, due to the degree of film blowing, which is usually in the range of 2-3. It should be kept in mind that the speed of film stretching along and across influences the orientation. The faster this speed is, the higher the film orientation. The transverse and longitudinal orientation of the film also affects the strength, as well as shrinkage of film. The problem when using different types of antistatic additives is the synergism of components used for a given application. For this reason, sometimes materials with very good functional properties do not show the same properties after blending and polymerization. The above inspires to look for appropriate compatibilizers [11]. Among many materials, for example, wax may be a good compatibilizer in some compositions, also improving the miscibility of ingredients, as well as processing.

\section{CONCLUSIONS}

The research conducted by AGH University of Science and Technology and Pakpoland Sp. z o.o. allowed using expanded graphite as an antistatic additive for polyethy- lene, which, with proper and effective mixing of powdered or liquid components, allows manufacturing thin free-standing films with a surface resistivity less than $10^{9} \Omega$, which is sufficient for antistatic materials. Content of $7 \mathrm{wt} \%$ of EG is optimal for antistatic behavior and proper mechanical properties of the films.

\section{REFERENCES}

[1] PlasticsEurope, Association of Plastics Manufacturers: Plastics-the Facts 2018.

https://www.plasticseurope.org/application/ files/6315/4510/9658/Plastics_the_facts_2018_AF_ web.pdf.

[2] Branża Tworzyw Sztucznych. Wzrost znaczenia polskich producentów na świecie: 2017.

https://wspieramyeksport.pl/raporty-branzowe/ B14.2/tworzywa-sztuczne.

[3] Polyolefins Market 2018-2023 Global Industry Report: 2018.

https://www.marketwatch.com/press-release/ polyolefins-market-2018-2023-global-industryperspective-latest-innovations-drivers-restraintschallenges-consumption-capacity-production-till-2023-2018-12-18.

[4] Passia H., Kędzierski P.: Bezpieczeństwo i Technika Pożarnicza 2015, 38 (2), 45.

[5] Stasiek J.: Polimery 2005, 50, 169. http://dx.doi.org/10.14314/polimery.2005.169

[6] Beaucage G., Rane S., Schaefer D.W. et al.: Journal of Polymer Science Part B Polymer Physics 1999, 37, 1105.

https://doi.org/10.1002/(S IC I) 1099 0488(19990601)37:11<1105::AID-POLB6>3.0.CO;2-5

[7] Imiołek P.G.: „Opracowanie polietylenu antystatycznego o zmniejszonej palności", MS Thesis 2017, AGH Kraków.

[8] Krupa I., Novak I., Chodak I.:Synthetic Metals 2004, 145, 245.

http://dx.doi.org/10.1016/j.synthmet.2004.05.007

[9] Sever K., Tavman I.H., Seki Y. et al.: Composites: Part B 2013, 53, 226.

https://doi.org/10.1016/j.compositesb.2013.04.069

[10] Lisowski L.: „Pomiar rezystywności i przenikalności elektrycznej dielektryków stałych", Oficyna Wydawnicza Politechniki Wrocławskiej, Wrocław 2004.

[11] Janik J., Lenart S., Królikowski W., Penczek P.: Polimery 2004, 49, 432.

http://dx.doi.org/10.14314/polimery.2004.432

Received 21 VIII 2019 